ISEP XIV

Correspondence

Max Taylor

maxt@unixg.ubc.ca

\section{The collapse of the two-kingdom system, the rise of protistology and the founding of the International Society for Evolutionary Protistology (ISEP)}

\author{
F. J. R. 'Max' Taylor \\ Department of Botany and Department of Earth \& Ocean Sciences, University of British \\ Columbia, Vancouver, BC, Canada V6T 1 Z4
}

\begin{abstract}
This paper provides a brief summary of the rise and acceptance of protistology as a modern, realistic approach to the evolutionary relationships and classification of unicellular eukaryotic organisms as well as the origins of the multicellular groups. The apparent reasons for the renaissance of this 19th-century concept in the 1970s are reviewed, with electron microscopy considered to be the key factor, strongly reinforced by molecular phylogenetic studies in the 1980s and 1990s. The foundation of the International Society for Evolutionary Protistology in 1975 accompanied this major alteration in the view of biological diversity. The current status of protistology relative to protozoology and phycology is discussed.
\end{abstract}

\section{Introduction: unity, dualism and pluralism}

During the latter part of the 20th century, several important 'paradigm shifts' occurred in our view of cell evolution. Perhaps the most obvious of these, because it was so hotly contested, was the symbiotic origin of mitochondria and chloroplasts. It was an old idea, with roots in the late 19th century, whose successful revival was championed by Margulis (1970). Ironically, although the symbiotic origin for these organelles has been generally accepted, her additional hypothesis of a symbiotic origin of the ' $9+2$ ' organelles (centrioles/basal bodies and derivative structures) as an origin for the eukaryotic mitotic process (Sagan, 1967) has not been supported by convincing evidence. Never one to quit, symbiotic spirochaete involvement is still espoused in her latest publication (Margulis \& Sagan, 2002). The formulation of a theory that incorporated hypotheses for the symbiotic origin of mitochondria and plastids sequentially was dubbed the 'serial endosymbiosis theory' (SET; Taylor, 1974) in a paper that also introduced the now widely used concepts of primary and secondary symbiosis that are particularly relevant to plastid acquisition.

A less obvious but equally important major paradigm shift was the resurrection and development of another 19thcentury concept: the protistological view of the basal nexus and radiation of unicellular eukaryotes preceding and giving rise to plants, animals and fungi but also many lineages independent of these multicellular groups. This replaced

This paper is a contribution to the proceedings of the XIVth meeting of the International Society of Evolutionary Protistology in Vancouver, Canada, 19-24 June 2002.

Published online ahead of print on 3 October 2003 as DOI 10.1099/ ijs.0.02587-0. the long-held subdivision of all eukaryotes, and even prokaryotes, into the classical plant and animal kingdoms.

The dualistic Plant-Animal view had its roots in Aristotle and his teacher Plato, in the Academy in Athens almost 2500 years ago (ca. 360 BC). Two living supergroups were formalized in 1735 by Carl von Linné in his monumental Systema Naturae as the Kingdoms Plantae and Animalia, into which all organisms were placed. By the 12th, and last, edition (Linnaeus, 1766), he had added a third kingdom of the natural world, Lapides (for 'rocks'; solid bodied, not living, not 'sentient', i.e. not having 'senses', a trait shared with plants in his scheme). This division of the living world was reflected in the disciplines of Botany and Zoology, housed in their own separate academic Departments for more than 250 years. Beginning in the mid 20th century, accompanying growing realization that plant and animal cells were fundamentally very similar in biochemistry, structure and genetic systems, a more common biological approach began. This was reinforced unequivocally by the 1960s discovery that all living beings use fundamentally the same genetic code.

As a result of these developments, Life Science departments or other disciplinary units began to replace the traditional departments by fusion and reorganization. Introductory biology courses began to replace introductory botany and zoology courses in the 1960s and the influential textbook The Science of Biology by Paul Weisz became widely used in introductory courses in North America.

Microbiology had separated earlier at many universities as a result of the recognition that the presence or absence of nuclei in cells was associated with other fundamentally 
different cell features and because of its medical bias. The French protistologist Édouard Chatton introduced the names 'prokaryotic' and 'eukaryotic' (with a ' $c$ ' instead of a ' $k$ '; Chatton, 1925), based simply on the absence or presence of nuclei, respectively (his 1938 publication is often given as the source, but this was a summary of earlier work; Chatton, 1938). This fundamental distinction of cell types led to an alternative dualistic view of two Kingdoms or Superkingdoms, Prokaryota and Eukaryota (e.g. Whittaker \& Margulis, 1978; Möhn, 1984).

\section{The protistan Renaissance}

The difficulty of assigning all things to the Lapides, Plantae or Animalia became increasingly evident in the mid- to late 19th century, especially between the latter two. Organisms, usually microscopic, combining features of both of the latter were discovered in the 19th century. As a result, it is now well known that John Hogg (1860) created a fourth kingdom, the Regnum Primigenum or Protoctista, meaning 'first beings' because they were believed to have arisen before plants and animals. It is ironic that two of the main examples Hogg used to bolster his arguments were not valid illustrations of the problem. One example was the freshwater green sponge, Spongilla, an animal that was known to give off oxygen in the light. In fact, the photosynthesis is due to symbiotic 'algae'. Another puzzle at the time was the nature of diatoms. Twenty-two years earlier, the great German microscopist Christian Gottfried von Ehrenberg had dogmatically asserted that they were tiny, 'complete' little animals (Infusionsthierchen als Volkomene Organismen), containing multiple stomachs (actually vacuoles) and other organs such as gonads (nuclei) and digestive glands (plastids). The 'cell theory' had not yet been formulated, and so there seemed to be no reason why such organs could not get smaller and smaller. In the $1840 \mathrm{~s}$, as the fundamental unitary nature of cells was being independently proposed by Mathias Schleiden and Theodore Schwann, Felix Dujardin showed that the cytoplasm (sarcode) of foraminiferans was not multicellular and Carl Theodor von Seibold established that they and other 'Protozoa' were unicellular.

As Whittaker \& Margulis (1978) noted, many early classifications were essentially 'top-down' views of the living world, tracing plants and animals downward into plant-like and animal-like 'lower organisms'. The German evolutionist, embryologist, microscopist, philosopher, artist and long-jump champion of Jena University, Ernst Haeckel, who was the strongest 19th century advocate of the distinctness of unicellular organisms, had a 'bottom-up' view, looking at the diversity of the living world from the earliest cells. $\mathrm{He}$ proposed that many groups evolved separately from the plant and animal lineages and, in 1866, only 7 years after the publication of Darwin's On the Origin of Species in 1859, named them members of the Protistenreich or Protist Kingdom, the Protista. Collectively, they were referred to as 'protists' [see the review by Rothschild (1989) for the origins and uses of such names and Ragan (1997) for a more detailed history of the concept]. Although his tree showed them as a sister group to animals and plants, the choice of name and the text indicated that he thought they arose before animals and plants. At first, he included sponges and fungi but, in his later publications (Haeckel, 1894, 1904), he explicitly restricted Protista to predominantly unicellular organisms or colonies not forming tissues. Bacteria were (understandably) included, first as Mychota and later as Monerans. Corliss (1998a, b) has recently reviewed the development of the concept of kingdom Protista extensively. Ernst Haeckel is clearly the 'Father of Protistology' as we know it.

Clifford Dobell (1911) seemed to champion this approach in his polemic, The Principles of Protistology, but he was mainly concerned with countering the reductionist view of protists as mere unicells, emphasizing their functional completeness as organisms (like Ehrenberg), and his scope in this and later publications was clearly traditionally protozoological. Further, he championed an 'acellular' view of protists, rather than unicellular. A debate about the unicellularity of protists carried on for nearly half a century, summarized by Corliss (1989a), but electron microscopy unequivocally showed that, with the possible exception of multinucleate cells, they are homologous with the single cells of multicellular eukaryotes, but do everything with only one such unit. In fact, the SET made clear that eukaryotic 'cells' with mitochondria are dyadic (digenomic) entities compared with prokaryotes and that those with plastids are triads (trigenomic; Taylor, 1974). This genomic complexity, arising from intracellular symbioses, was believed to be the source of major evolutionary novelty by Ivan Wallin (1927) in the same work in which he proposed a symbiotic origin for the mitochondrion. He viewed this as a new form of speciation termed 'symbionticism', considering it to be more important in evolution than mutation. These concepts have been evaluated by Taylor (1980a, 1983, 1987a), who concluded that he failed to convince others because of his excessive 'overselling' of symbionticism, and Sapp (1995). Using Mereschkowsky's term 'symbiogenesis', Margulis \& Cohen (1994) discussed its possible potential for innovation in a paleo-evolutionary context, and Margulis \& Sagan (2002) have promoted its importance as a speciation mechanism to a wider audience.

Herbert F. Copeland tried to bring the Protoctista back formally in 1938 and, in an extensive, thorough book (Copeland, 1956), offered a complete, unified reclassification of 'lower organisms', but his efforts were to no avail. Werner Rothmaler's system, with Protobionta as a comparable category, was also greeted largely with indifference (Rothmaler, 1948). Algae, fungi and protozoa were far too entrenched in their traditional departments to change radically and were formally supported by the International Codes of Botanical and Zoological Nomenclature. Twenty years later, the ecologist Robert $\mathrm{H}$. Whittaker took the protistological baton and ran with it, reviving Haeckel's Kingdom Protista, together with a separate kingdom for Fungi (Whittaker, 1959), following it with a major article 
introducing his Five Kingdom system in the usually conservative pages of Science (Whittaker, 1969). However, both these and later versions, such as that with Margulis (Whittaker \& Margulis, 1978), still retained polyphyletic groups such as zoo- and phytoflagellates as precursor branches of animal or plant protist lineages. Emphasis was on macroclassification rather than on actual protist affinities.

These bold, perceptive individuals kept the protistan concept going but couldn't accomplish a general fundamental change in biologists' thinking. After all, all biologists received the same training in 'lower organisms', usually strong in only the material taught by one or other department. However, when Paul Weisz responded to the demand for an integrative biology text to be used at the introductory university level, he responded with The Science of Biology, in which he followed Copeland and Whittaker and used Protists as a major group (Kingdom) in place of Protozoa, Algae and Fungi and uniting the two former. However, no sooner had students passed beyond first year, their conceptual framework regressed 50 years, back to the traditional categories of Algae, Protozoa and Fungi.

Protozoa were traditionally classified as the simplest phylum of the Invertebrata, even by the most authoritative invertebratologist of the first half of the 20th century, the American Libbie Hyman. As recently as 1991, at the insistence of the editor, protozoa still were (Corliss, 1991, with a caveat that they were included only for 'completeness'). Protist groups are still being added to the Treatise on Invertebrate Paleontology. In a contribution on Protozoa for a symposium on 'Invertebrate classification and phylogeny', organized by Hyman in 1959, John Corliss concluded that: 'the outlook for a good, defensible understanding of any phylogenetic relationships involving Protozoa is as discouraging as it ever was' (Corliss, 1959, p. 169).

The desire for change was strong in the late 1950s but the data needed were not yet at hand.

\section{Electron microscopy reveals cross-kingdom affinities in eukaryotes and roots the Metazoa and Metaphyta (and Fungi)}

In fact, the data for a major shake-up were just becoming available (Taylor, 1976, 1978). Beginning in the late 1950s, Irene Manton pioneered the application of the transmission electron microscope (TEM) to study the ultrastructure of photosynthetic protists, and she was soon joined by Dorothy Pitelka (heterotrophic protists) and others more concerned with the techniques themselves. A whole new, rich dataset became available for comparisons across all the eukaryotic group boundaries and, thanks to the observation of slices through many individuals simultaneously, it was possible to get a strong sense of the degree of variability to be expected in each. It also established the homology of many structures disguised under different names. For example, cilia and flagella were found to be identical in basic structure, with an extraordinary conservatism of the ' $9+2$ ' microtubular arrangement of basal bodies, and centrioles were clearly homologous with them. Bacterial flagella were shown to be not only much smaller but fundamentally different in structure, composition and function. The eukaryotic structures have historical precedence for the name: Flagellaten was a major protozoan cell type ever since Bütschli (1880-1889), the Flagellata being one of four major Superclasses of the Protozoa in Grassé (1952), subdivided into phytoflagellates and zooflagellates. 'Flagellates' and 'flagella' have prevailed, despite attempts to replace the name of the eukaryotic structures with 'undulipodia' (all papers by Margulis since the 1970s) or the use of cilia for all of them (Hülsmann, 1992; all papers by Cavalier-Smith over the same period). If 'flagellum' is ambiguous, it is no more so than 'cell', and the context should leave no doubt as to the structure referred to.

The basic structures of nuclei, mitosis, mitochondria and chloroplasts were soon shown to be essentially similar in all eukaryotes, both protists and multicellular organisms, but differed in details, some of which were group specific, e.g. internal or external spindles (the former apparently being earlier in origin). Golgi bodies and dictyosomes were shown to be fundamentally the same in animal and plant cells, respectively. At the same time, a whole new fine-structural dataset became available for comparative purposes that covered the whole, or most, of the range of eukaryotes.

The outcome of the application of these data, reviewed by Taylor (1994, 1999) and Patterson (1999, 2000) among others, was no less than a revolution in our view of the relationships of the 'lower eukaryotes'. Many long-standing categories, such as Algae, Fungi, Protozoa, amoebae, heliozoans, Phytoflagellates, Zooflagellates, etc., were shown to be polyphyletic. As a result of the protistological approach, ignoring the old boundaries, new probable relationships were recognized, such as euglenoids with trypanosomes, based initially on their paddle-shaped cristae (Taylor, 1976), but soon reinforced by several other features (Kivic \& Walne, 1984). Ciliates were linked with dinoflagellates on the basis of their cortical structural similarities (Taylor, 1976; suggested also by Corliss, 1975). Oomycetes resembled xanthophytes and other protists with compound flagellar hairs (Taylor, 1978). Corliss (1986) dated the 're-emergence of the field [protistology] as a respectable interdisciplinary area' from the mid-1970s, the same period in which the International Society for Evolutionary Protistology (ISEP) was founded (see below).

As lineages became clearer, it was also realized that ultrastructural characters might help to distinguish between competing hypotheses for the protistan roots of plants and animals. It had long been evident that the chlorophytes were the most likely candidates for the origin of plants, given the near-identity of biochemical characters (pigments, storage). Copeland even placed them within the same Kingdom Plantae. Ultrastructure cemented this, showing that that the chlorophyll $\mathrm{a}+\mathrm{b}$-containing plastids had only two membranes around them and that starch was located within the plastids, like plants. It even offered clues as to where 
within the chlorophytes (including prasinomonads) the divergence may have occurred, scaly flagella occurring in the sperm of mosses and ferns. Ultrastructure of choanoflagellates was consistent with the long-held view of them as animal ancestors, based on the resemblance to choanocytes of sponges, but a ciliate ancestry had been proposed by Hadzi and Hanson. Ciliates are strongly tubulocristate (Taylor, 1978). The flat mitochondrial cristae and flagellar roots of sponge choanocytes were consistent with the choanoflagellate origin hypothesis dating back to Saville Kent a century before (see Corliss, 1989b for a review).

In the mycological world, it was widely accepted that slime moulds (especially the acrasiids) and phycomycetes (flagellated 'water moulds') seemed to differ from other 'fungi' in a number of ways. Electron microscopy strengthened these differences, zygo-, asco- and basidiomycetes lacking any trace of ' $9+2$ ' structures, including flagella, and having flat mitochondrial cristae. The phycomycetes had tubular cristae with one notable exception: chytrids differed from the other phycomycetes, not only in having a posterior, smooth flagellum, but also in having flat cristae (Taylor, 1978). Molecular sequence comparisons (see below) eventually showed that chytrids were the nearest flagellated sister-group of the 'true fungi', the other phycomycetes, with tubular cristae, being linked to the stramenopiles/ heterokonts. In another example, mitochondrial cristae can be used as a key criterion in the recognition of natural groups of amoebae, separating the heteroloboseans (discoidal cristae) from the gymnamoebae (tubular cristae, sometimes branching/ramicristate) of Rogerson \& Patterson (2000). Time has only strengthened the surprising conservatism and consequent usefulness of crista-type within protist groups in indicating major clusters, such as discicristate, tubulocristate and platycristate protists (Gray et al., 1998; Taylor, 1994, 1999; Patterson, 1999). Wellknown exceptions include the size reduction of the cristae in low-oxygen conditions, as in some trypanosomes. The position of cryptomonads continues to be troublesome, with some molecular evidence indicating the placement of cryptomonads (flat cristae) with the chromalveolates (tubular) (Fast et al., 2001; Yoon et al., 2002), although the use of plastid characters to place the 'host' phylogenetic position can be questioned. The position of Dictyostelium (tubular cristae) closer to animals (flat) than plants (also flat) (Bapteste et al., 2002) contradicts the monophyly of flat cristae. Time and the use of various criteria, including multiple genes and mitochondrial DNA, will tell whether these and others are undoubted exceptions to the rule.

\section{Formal treatments of protists}

In my own attempts to seek out protistan group relationships in the 1970s, the conventional categories and boundaries were disregarded. This was not difficult, because I worked with natural microplankton communities in which the similarities between various groups of protists, other than the presence or absence of plastids, were more obvious than their differences. Instead, the form category 'flagellates' was used (Taylor, 1976), or the now frowned-upon 'lower eukaryotes' (Taylor, 1978). It had become evident through these and earlier independent efforts that protists were a diverse radiation of early diverging eukaryotes in which multicellularity had evolved repeatedly, independently: many groups had remained unicellular, but others had given rise to multicellular photosynthetic and non-photosynthetic groups including the plants and animals. Defining a formal group 'Protista', using Haeckel's unicellularity criterion, would orphan several multicellular groups not closely related to animals and plants, such as the 'brown algae', and raise problems in groups that have both. Such a kingdom would thus be a 'grade' or level-of-organization, which is not acceptable in formal classification among phylogenetic systematicists, since the group Protista would not include all its descendants, i.e. was paraphyletic. This is also true of the group Protoctista, which includes some multicellular descendants but not all. The avoidance of paraphyly, while theoretically laudable, seems almost impossible to reconcile with classical systematics. Alternatively, according each major clade kingdom status leads to taxon inflation to an extreme degree. The Five Kingdom/Two Superkingdom approach is intuitively appealing in its simplicity of concept, but is weak in its theoretical underpinnings and needs to be reconciled with the Three Domain (Bacteria, Archaea, Eukaryota) view arising from SSU rDNA trees. The Kingdom Protoctista has been strongly advocated by Margulis in the Handbook (Margulis et al., 1990) and as one of the 'five kingdoms' that she has popularized significantly in recent years (Margulis \& Schwartz, 1998). Although fuzzy on detailed relationships, there is no doubt that these works have substantially opened the minds of educators to the protistan alternative.

Given the state of knowledge prevailing in the 1970s and 1980s, a detailed new classification beyond that of Copeland (1956) would have had to undergo repeated conceptual and nomenclatural changes. Others have accepted the challenge, notably Cavalier-Smith (1981, 1993, 1998; and many other contributions up to this volume). This iterative approach should eventually lead to a more robust classification but, unfortunately, it generates new names and differing uses of old names as it goes. Corliss (1972) appealed for common sense and courtesy in such matters to avoid the proliferation of new higher taxa. The whole systematic question has been reviewed in detail by several authors, including Möhn (1984), Cavalier-Smith (1998), Corliss (1998a, 2002) and Patterson $(1999,2000)$.

Another approach, currently in vogue, is to depict the relationships of many of the definable 75 or so protist lineages as a 'comb', in which most have no sister groups (e.g. Patterson, 1999, 2000). However, the aggregation of groups according to mitochondrial crista types, as Patterson (2000) has noted, does seem to be remarkably concordant with several molecular datasets, including rDNA and mitochondrial DNA.

The literal meaning of the formal names of protist groups 
currently in use has been commented on elsewhere (Taylor, 1999). I regret the continuation of anachronistic and inappropriate group-endings such as -zoa, -phyta and - mychota, except where they are literally apt. Also, the use of 'Protozoa' to include many more groups than usual, including some that are poly- or paraphyletic, seems unfortunate and likely to mislead the unknowing or unwary [see Patterson (2000) for a more detailed criticism and Corliss (2002), which includes a brief rebuttal].

\section{The International Society for Evolutionary Protistology (ISEP)}

Although the details of the society's early history are not appropriate here, a brief summary, based on personal experience, does seem to be à propos since it coincided with the developments described above and since the present publication concerns one of its meetings. The formation of a society concerned with early events in eukaryotic evolution was discussed by Lynn Margulis, Max Taylor and Howard Whisler in Seattle, USA, in late 1973, following the First International Congress of Systematic and Evolutionary Biology in Boulder, USA, where the SET had its first formal discussion and a protistan session was also held. It was formally proposed, with election of an ad hoc editorial committee, at a meeting on the origin and evolution of mitosis in Boston, USA, in 1974 (see Margulis \& Taylor, 1975), and this has been taken as the first Society for Evolutionary Protistology (SEP) meeting. The second, convened in Toronto, Canada, was summarized by Heath (1978). The word 'International' was added after the fourth meeting, held in Maryland, USA (see Goode \& Corliss, 1981, 1982), and the society was formally incorporated in 1982.

There have been 11 other meetings (the proposed third meeting, in the UK, was cancelled), held in the USA, Canada, France, Germany, the UK and the Czech Republic, some of which were held jointly with other societies. There has never been an independent, society-sponsored journal. The earliest proceedings were published in BioSystems. Some of the proceedings of the 13th meeting were, like the present, published in the International Journal of Systematic and Evolutionary Microbiology (Farmer, 2001), and a summary of the 14th meeting was presented by Dacks \& Simpson (2002).

\section{The present and the future}

More than a decade ago, most of the primary lineages of protistan evolution had been revealed by electron microscopy [45 in 1984 (Corliss, 1984); mostly twigs with few branches], although the branch order was still wide open. As I have noted before (Taylor, 1978, 1994, 1999), the chief problem with the TEM-based tree was that the root could only be hypothesized on the basis of the absence of nearuniversal eukaryotic characters (mitochondria, ' $9+2$ ' structures, histones), never a satisfactory approach, since there was no way at the time to distinguish primary absence from loss. Molecular sequence comparisons offered the exciting possibility of rooting the tree with the use of positive genome sequence characters and the search for traces in nuclei of former organelle genomes. This premise has not proved simple to apply.

Unquestionably, it has been the rapid growth of molecular phylogenetics (Taylor, 1994, 1999; Cavalier-Smith, 1995; Patterson, 2000) that has kept the interest in eukaryotic macro-evolution strong and the evolutionary protistan pot simmering: molecular sequencing continues to provide new insights, cement protistan relationships and raise new debates, particularly as different molecules and different methods yield differing results. 5S rDNA trees obviously had anomalous features, attributed to the small size of the molecule and the correspondingly small amount of usable nucleotide sequence variation. LSU rRNA genes are so large and hypervariable in multiple regions that the latter need to be selectively removed in order to study group-level relationships (e.g. Ben Ali et al., 2001). In the 1980s and 1990s, SSU rDNA seemed to be 'just right' in size and information content for the latter purpose. In broad features, the trees it generated corresponded well with the main features of the TEM data (Sogin, 1994; Sogin et al., 1996; Taylor, 1994). Now, finally, it seemed that there was a molecule that could be used to resolve which of the 'absence/ loss' choices was actually a primary absence. Some of the amitochondriate groups, such as the diplomonads and parabasalians and microsporidia, were basal in SSU rDNA trees. However, they were long branches and therefore potentially subject to a methodological artefact that made their placement suspect. In any case, new molecular evidence was emerging that revealed the presence of mitochondrial genes in the nuclei of these amitochondriate groups (Keeling, 1998; Roger, 1999).

Once again, in protistan phylogenetic study, a promising new class of data proved not as simple to apply as it first appeared. I am reminded of how, during the TEM revolution, different authorities believed that study of their organelle would be the golden key that unlocked the door to reveal the 'real tree' of the eukaryotes (I could certainly now be accused of 'mitochondriocentricism', if such a term existed). So too with the genes. As Ben Ali and his colleagues concluded: 'despite considerable debate on the vices and virtues of various molecular phylogenetic markers, all have their strengths and weaknesses' (Ben Ali et al., 2001, p. 744).

Favourite molecules? Favourite organelles? All this brings to mind the typically memorable remark of New York baseball legend Lawrence 'Yogi' Berra: 'It's déjà vu all over again!'

It is clear that all possible datasets are needed to act as tests of hypotheses generated by each other, and it is unlikely that one set will be equally useful over the whole range of the eukaryotes (Taylor, 1978).

If protistology is now an established field, what has happened to the disciplines that formerly dealt with protists? 
Of course, they're still there. While demonstrated polyphyly is now deemed sufficient to discard formal systematic groups, there is no compelling reason to eliminate specializations based on them. For example, parasitologists study highly polyphyletic subject taxa and this has not been a problem.

Traditional protozoology, focussed primarily on non-fungal unicellular heterotrophic eukaryotes, but also including 'phytoflagellate' groups in which both photosynthetic and non-photosynthetic members exist, is still alive and well. This is evidenced by the highly useful Illustrated Guide to the Protozoa (Lee et al., 2000), covering the traditional groups. Protozoology is now essentially a subset of the groups contained within protistology sensu lato. There are still protozoologists in protistan clothing, even among those using 'protists' in paper titles but with the contents still traditionally protozoological. In France, protozoologists have long been known as 'protistologues', although the scope of their studies has been explicitly protozoological, even when published in Protistologica (now the European Journal of Protistology and truly protistological). The Précis de Protistologie (de Puytorac et al., 1987) is purely protozoological in scope. Despite its title, the Archiv für Protistenkunde (now Protist) has also been protozoological throughout most of its long history. Traditional background-training limitations are understandably difficult to transcend, with occasional lapses even by the enlightened. Alas, the choice of six pre-eminent, contemporary, taxonomically adept 'protistological ecologists' (Corliss, 1992) was unintentionally restricted to some who have focused on heterotrophic eukaryotes. So too, the citation of 24 publications on 'protistan ecology' (Corliss, 2002) only listed those dealing with non-photosynthetic protists, except for one partially so (chrysomonads). Diatoms, dinoflagellates, cryptomonads, silicoflagellates et al. are just as protistan as ciliates or foraminiferans and are ecologically as important, or much more so in aquatic environments.

A wider protistan scope is essential in the study of biodiversity and biocomplexity, as well as ecology. For example, recent claims that protists ('microbial eukaryotes') are essentially cosmopolitan, lacking in distinctive biogeographical distributions [e.g. Patterson \& Lee (2000) (explicitly for flagellates) and Finlay (2002)], apparently result from the use of examples from extreme environments and the neglect of marine microplanktonic communities that cover $70 \%$ of the Earth's surface. Near ubiquitousness and random dispersal may be semi-true for terrestrial and other harsh-environment protists, but is contrary to a huge body of marine planktonic and sedimentary record literature dating back to the 19th century (see Taylor, 1980b; summed up for dinoflagellates by Taylor, 1987b). Although marine protists are mostly circum-global ('latitudinally cosmopolitan'; Taylor, 1987b), their dispersal is controlled largely by currents and is strongly influenced by benthic or planktonic habitats, temperature and proximity to the continental shelf (oceanic, neritic). Oceanic, tropical species, for example, are greatly different from polar ice species or even coastal tropical species. Whole groups, such as the acantharians or polycystine radiolarians, are restricted to, or are found predominantly in, subtropical-tropical marine waters. Symbioses of protists, usually photosynthetic cytobionts with non-photosynthetic protist or invertebrate hosts, are far more common in the tropics than in colder waters (Taylor, 1982, 1990). Endemicism is rare, but apparently does exist in South-East Asian waters. Green Noctiluca, containing a symbiotic prasinomonad, are restricted to these high-diversity waters (Taylor, 1990), and so are a few other dinoflagellates, such as Dinophysis miles var. schroteri (Taylor, 1987b).

Contemporary mycologists appropriately focus on the organisms that make up the monophyletic, platycristate lineage (kingdom) composed of chytrids, the Eufungi and, most recently, microsporidians. The other, unrelated fungallike groups grouped with them in the past (slime moulds/ myxozoans, oomycetes, hyphochytrids) are evidently related to the tubulocristate protists, although they are still studied primarily by mycologists for non-phylogenetic reasons.

Phycology still flourishes as a discipline, although several of its major component groups, particularly the 'Big Three' (Reds, Greens, Browns), are not closely related, although reds are closer to greens than browns, and the informal group 'Algae' is polyphyletic (Taylor, 1978; Bhattacharya \& Medlin, 1998; Graham \& Wilcox, 2000; and references therein). The strong acceptance of 'algal protists' into the phycological fold is illustrated by the inclusion of several papers on dinoflagellates in virtually every recent issue of the Journal of Phycology, and the logo of the Phycological Society of America is a rosette of ceratioid dinoflagellates. Green algae (prasinomonads, chlorophytes, charophytes) are indisputably on the same major lineage as metaphytes (streptophytes), good structural, biochemical and molecular evidence that higher plants evolved from within the greens, and have therefore been placed together in the Plantae (Copeland, 1956) or Viridaeplantae (Cavalier-Smith, 1981). The red algae are more isolated, but are arguably not far from the green algae (Ragan \& Gutell, 1995). On the other hand, based on sperm flagellar structure and plastid features, the tubulocristate brown algae can reasonably be viewed as derived from, and classificatorily included in, the stramenopiles/heterokonts, a large clade of multiple names and including both photosynthetic and non-photosynthetic member groups. Linking this assemblage with the alveolates would accord with their common possession of tubular cristae (Taylor, 1994, 1999).

The challenge for the future will be how best to realign these disciplines in a way that makes 'natural' classificatory sense. For those who continue to work comfortably within the traditional disciplines, I offer this gratuitous homily: act as a protozoologist, mycologist or phycologist, but please think as a protistologist! 


\section{Envoi}

Alexander the Great was required to untie the Gordian knot on a chariot harness in order to become the ruler of Asia Minor. According to popular legend, he succeeded by chopping it in two. As a young person, I did not find this particularly edifying, and still do not. It was cheating, and it seems particularly apt that it was a protist, Plasmodium, that terminated not only his conquests, but also him! The eukaryotic evolutionary knot needs to be properly untied. ISEP has made a good start, and I hope that it will be busily unravelling it for a long time to come.

\section{Acknowledgements}

This paper is also published to mark the 80th birthday of our colleague, John O. Corliss, in February 2002. Since John is one of the most active writers on the topics covered here, and since our interests are very similar, although our backgrounds and viewpoints differ somewhat, this tribute seems to be appropriate.

\section{References}

Bapteste, E., Brinkmann, H., Lee, J. A. \& 8 other authors (2002). The analysis of 100 genes supports the grouping of three highly divergent amoebae: Dictyostelium, Entamoeba, and Mastigamoeba. Proc Natl Acad Sci U S A 99, 1414-1419.

Ben Ali, A., De Baere, R., Van der Auwera, G., De Wachter, R. \& Van de Peer, Y. (2001). Phylogenetic relationships among algae based on complete large-subunit rRNA sequences. Int J Syst Evol Microbiol 51, 737-749.

Bhattacharya, D. \& Medlin, L. (1998). Algal phylogeny and the origin of land plants. Plant Physiol 116, 9-15.

Bütschli, O. (1880-1889). Protozoa. I, II, III. In Klassen und Ordnung des Thier-Reichs, vol. I, pp. 1-2035. Edited by H. G. Bronn. Leipzig: C. F. Winter (in German).

Cavalier-Smith, T. (1981). Eukaryote kingdoms: seven or nine? Biosystems 14, 461-481.

Cavalier-Smith, T. (1993). Kingdom Protozoa and its 18 phyla. Microbiol Rev 57, 953-994.

Cavalier-Smith, T. (1995). Evolutionary protistology comes of age: biodiversity and molecular cell biology. Arch Protistenk 145, 145-154.

Cavalier-Smith, T. (1998). A revised six-kingdom system of life. Biol Rev Camb Philos Soc 73, 203-266.

Chatton, É. (1925). Pansporella perplexa, amoebiens à spores protégées parasite de daphnies. Réflections sur la biologie et la phylogénie des protozoaires. Ann Sci Nat Zool (Sér. 10) 8, 5-84 (in French).

Chatton, É. (1938). Titres et Travaux Scientifiques (1906-1937). Sète: E. Sottano (in French).

Copeland, H. F. (1956). The Classification of Lower Organisms. Palo Alto, CA: Pacific Books.

Corliss, J. O. (1959). Comments on the systematics and phylogeny of the Protozoa. Syst Zool 8, 169-190.

Corliss, J. O. (1972). Common sense and courtesy in nomenclatural taxonomy. Syst Zool 21, 117-122.

Corliss, J. O. (1975). Nuclear characteristics and phylogeny in the protistan phylum Ciliophora. Biosystems 7, 338-349.

Corliss, J. O. (1984). The kingdom Protista and its 45 phyla. Biosystems 17, 87-126.
Corliss, J. O. (1986). Progress in protistology during the first decade following reemergence of the field as a respectable interdisciplinary area in modern biological research. Prog Protistol 1, 11-63.

Corliss, J. O. (1989a). The protist and the cell: a brief twentiethcentury overview. J Hist Biol 22, 307-323.

Corliss, J. O. (1989b). Protistan diversity and origins of multicellular/multi-tissued organisms. Boll Zool 56, 227-234.

Corliss, J. O. (1991). Introduction to the Protozoa. In Microscopic Anatomy of Invertebrates, vol. 1, Protozoa, pp. 1-12. Edited by F. W. Harrison \& J. O. Corliss. New York: Wiley-Liss.

Corliss, J. O. (1992). The interface between taxonomy and ecology in modern studies on the protists. Acta Protozool 31, 1-9.

Corliss, J. O. (1998a). Classification of protozoa and protists: the current status. In Evolutionary Relationships among Protozoa, pp. 409-447. Systematics Association special volume no. 56. Edited by G. H. Coombs, K. Vickerman, M. A. Sleigh \& A. Warren. Dordrecht: Kluwer Academic.

Corliss, J. O. (1998b). Haeckel's kingdom Protista and current concepts in systematic protistology. Stapfia 56, 85-104.

Corliss, J. O. (2002). Biodiversity and biocomplexity of the protists and an overview of their significant roles in maintenance of our biosphere. Acta Protozool 41, 199-219.

Dacks, J. B. \& Simpson, A. G. B. (2002). Meeting report: XIVth meeting of the International Society for Evolutionary Protistology, Vancouver, Canada, June 19-24, 2002. Protist 153, 337-342.

de Puytorac, P., Grain, J. \& Mignot, J.-P. (1987). Précis de Protistologie. Paris: Société Nouvelle des Éditions Boubée (in French).

Dobell, C. C. (1911). The principles of protistology. Arch Protistenk 23, 269-310.

Farmer, M. A. (2001). ISEP XIIIth meeting, České Budějovice. Int J Syst Evol Microbiol 51, 729.

Fast, N. M., Kissinger, J. C., Roos, D. S. \& Keeling, P. J. (2001). Nuclear-encoded, plastid-targeted genes suggest a single common origin for apicomplexan and dinoflagellate plastids. Mol Biol Evol 18, 418-426.

Finlay, B. J. (2002). Global dispersal of free-living microbial eukaryote species. Science 296, 1061-1063.

Goode, D. \& Corliss, J. O. (1981). Meeting report: Conference on Cellular Evolution. Biosystems 14, 229-230.

Goode, D. \& Corliss, J. O. (1982). Meeting report: Conference on Cellular Evolution. Cell Motil 2, 83-89.

Graham, L. E. \& Wilcox, L. W. (2000). Algae. Upper Saddle River, NJ: Prentice Hall.

Grassé, P.-P. (editor) (1952). Traité de Zoologie. Phylogenie. Protozoaires: Généralités. Flagellés, vol. 1, pp. 1-1071. Paris: Masson (in French).

Gray, M. W., Lang, B. F., Cedergren, R. \& 12 other authors (1998). Genome structure and gene content in protist mitochondrial DNAs. Nucleic Acids Res 26, 865-878.

Haeckel, E. (1894). Systematische Phylogenie. I. Systematische Phylogenie der Protisten und Pflanzen. Berlin: Reimer (in German).

Haeckel, E. (1904). The Wonders of Life: a Popular Study of Biological Philosophy. New York: Harper.

Heath, I. B. (1978). Society for Evolutionary Protistology - meeting on the validity of phylogenetic criteria for protistans. Biosystems 10, $1-2$.

Hogg, J. (1860). On the distinctions of a plant and an animal and on a fourth kingdom of Nature. Edinb $N$ Phil J (N Ser) 12, 216-225.

Hülsmann, N. (1992). Undulipodium: end of a useless discussion. Eur J Protistol 28, 253-257. 
Keeling, P. J. (1998). A kingdom's progress: Archezoa and the origin of eukaryotes. Bioessays 20, 87-95.

Kivic, P. A. \& Walne, P. L. (1984). An evaluation of a possible phylogenetic relationship between the Euglenophyta and Kinetoplastida. Origins Life 13, 269-288.

Lee, J., Leedale, G. F. \& Bradbury, P. (editors) (2000). An Illustrated Guide to the Protozoa, 2nd edn. Lawrence, KA: Society of Protozoologists (actual date of appearance, 2002).

Linnaeus, C. (1766). Systema Naturae: sive Regna Tria Naturae Systematice Proposita per Classes, Ordines, Genera et Species, 12th edn. Stockholm: Holmiae (in Latin).

Margulis, L. (1970). Origin of Eukaryotic Cells. New Haven, CT: Yale University Press.

Margulis, L. \& Cohen, J. E. (1994). Combinatorial generation of taxonomic diversity: implication of symbiogenesis for the Proterozoic fossil record. In Early Life on Earth, pp. 327-333. Nobel Symposium no. 84. Edited by S. Bengtson. New York: Columbia University Press.

Margulis, L. \& Sagan, D. (2002). Accumulating Genomes. A Theory of the Origins of Species. New York: Basic Books.

Margulis, L. \& Schwartz, K. V. (1998). Five Kingdoms: an Illustrated Guide to the Phyla of Life on Earth, 3rd edn. New York: W. H. Freeman.

Margulis, L. \& Taylor, F. J. R. (1975). Symposium on the evolution of mitosis in eukaryotic organisms: introduction. Biosystems 7, 295-297.

Margulis, L., Corliss, J. O., Melkonian, M. \& Chapman, D. J. (editors) (1990). Handbook of Protoctista. Boston: Jones \& Bartlett.

Möhn, E. (1984). System und Phylogenie der Lebewesen. I. Physikalische, chemische und biologische Evolution. Prokaryonta. Eukaryonta. Stuttgart: E. Schweizerbart'sche Verlagsbuchhandlung (in German).

Patterson, D. J. (1999). The diversity of eukaryotes. Am Nat 154 (Suppl. 4), S96-S124.

Patterson, D. J. (2000). Changing views of protistan systematics: the taxonomy of protozoa - an overview. In An Illustrated Guide to the Protozoa, 2nd edn, pp. 2-9. Edited by J. Lee, G. F. Leedale \& P. Bradbury. Lawrence, KA: Society of Protozoologists (actual date of appearance, 2002).

Patterson, D. J. \& Lee, W. J. (2000). In The Flagellates, pp. 269-287. Edited by B. S. C. Leadbeater \& J. C. Green. London: Taylor \& Francis.

Ragan, M. A. (1997). A third kingdom of eukaryotic life: history of an idea. Arch Protistenk 148, 225-243.

Ragan, M. A. \& Gutell, R. R. (1995). Are red algae plants? Bot J Linn Soc 118, 81-105.

Roger, A. J. (1999). Reconstructing early events in eukaryotic evolution. Am Nat 154 (Suppl. 4), S146-S163.

Rogerson, A. \& Patterson, D. J. (2000). The naked ramicristate amoebae (Gymnamoebae). In An Illustrated Guide to the Protozoa, 2nd edn, pp. 1023-1052. Edited by J. Lee, G. F. Leedale \& P. Bradbury. Lawrence, KA: Society of Protozoologists (actual date of appearance, 2002).

Rothmaler, W. (1948). Über das natürliche System de Organismen. Biol Zentbl 67, 242-250 (in German).

Rothschild, L. J. (1989). Protozoa, Protista, Protoctista: what's in a name? J Hist Biol 22, 277-305.

Sagan, L. (1967). On the origin of mitosing cells. J Theor Biol 14, 255-274.
Sapp, J. (1995). Cell evolution and organelle origins: metascience to science. Arch Protistenk 145, 263-275.

Sogin, M. L. (1994). The origin of eukaryotes and evolution into major kingdoms. In Early Life on Earth, pp. 181-192. Nobel Symposium no. 84. Edited by S. Bengtson. New York: Columbia University Press.

Sogin, M. L., Morrison, H. G., Hinkle, G. \& Silberman, J. D. (1996). Ancestral relationships of the major eukaryotic lineages. Microbiol SEM 12, 17-28.

Taylor, F. J. R. (1974). Implications and extensions of the Serial Endosymbiosis Theory of the origin of eukaryotes. Taxon 23, 229-258.

Taylor, F. J. R. (1976). Flagellate phylogeny: a study in conflicts. J Protozool 23, 28-40.

Taylor, F. J. R. (1978). Problems in the development of an explicit hypothetical phylogeny of the lower eukaryotes. Biosystems 10, 67-89.

Taylor, F. J. R. (1980a). The stimulation of cell research by endosymbiotic hypotheses for the origin of eukaryotes. In Endocytobiology. Endosymbiosis \& Cell Biology: a Synthesis of Recent Research, vol. 1, pp. 917-942. Edited by W. Schwemmler \& H. Schenk. Berlin: Walter de Gruyter.

Taylor, F. J. R. (1980b). Phytoplankton ecology before 1900: supplementary notes to "The Depths of The Ocean". In Oceanography: the Past, pp. 509-521. Edited by M. Sears \& D. Merriman. New York: Springer.

Taylor, F. J. R. (1982). Symbioses in marine microplankton. Ann Inst Oceanogr Paris 58, 61-90.

Taylor, F. J. R. (1983). Some eco-evolutionary aspects of intracellular symbiosis. Int Rev Cytol Suppl. 14, 1-28.

Taylor, F. J. R. (1987a). An overview of the status of evolutionary cell symbiosis theories. Ann N Y Acad Sci 503, 1-16.

Taylor, F. J. R. (1987b). Ecology of dinoflagellates. A. General and marine ecosystems. In The Biology of Dinoflagellates, pp. 398-502. Edited by F. J. R. Taylor. Oxford: Blackwell Scientific.

Taylor, F. J. R. (1990). Symbiosis in marine protozoa. In The Ecology of Marine Protozoa, pp. 323-340. Edited by G. M. Capriulo. New York: Oxford University Press.

Taylor, F. J. R. (1994). The role of phenotypic comparisons in the determination of protist phylogeny. In Early Life on Earth, pp. 312-326. Edited by S. Bengtson. Nobel Symposium no. 84. New York: Columbia University Press.

Taylor, F. J. R. (1999). Ultrastructure as a control for protistan molecular phylogeny. Am Nat 154 (Suppl. 4), S125-S136.

Wallin, I. E. (1927). Symbionticism and the Origin of Species. London: Ballière, Tindall \& Cox.

Whittaker, R. H. (1959). On the broad classification of organisms. Q Rev Biol 34, 210-226.

Whittaker, R. H. (1969). New concepts of kingdoms of organisms. Evolutionary relations are better represented by new classifications than by the traditional two kingdoms. Science 163, 150-160.

Whittaker, R. H. \& Margulis, L. (1978). Protist classification and the kingdoms of organisms. Biosystems 10, 3-18.

Yoon, H. S., Hackett, J. D., Pinto, G. \& Bhattacharya, D. (2002). The single, ancient origin of chromist plastids. Proc Natl Acad Sci U S A 99, 15507-15512. 